\title{
Comparison of capilary glycemic responses after moderated continuous racing and high-intensity interval training in diabetes type 1 patients
}

\author{
Brenda Bauth Barros Oliveira, Nadjara Silva Viana, William Valadares Campos Pereira*, Albená Nunes da Silva \\ From 20th Brazilian Diabetes Society Congress \\ Porto Alegre, Brazil. 11-18 November 2015
}

\section{Background}

Variations of glucose levels in patients with diabetes type 1 (DM1) in response to different types of exercise protocols are still unclear. This knowledge would permit a more accurate exercise prescription to these specific subjects and augment the security of its performing.

\section{Objective}

The aim of this study was to compare the glycemic response of DM1 subjects after moderate-intensity continuous running protocol (MI) and high-intensity Interval training (HIIT).

\section{Materials and methods}

Seven men with DM1, aged $26 \pm 6.63$ yrs., BMI $24 \pm 1.99 \mathrm{~kg} /$ $\mathrm{m} 2$, with DM1 duration of $15 \pm 9$ yrs., HbA1c $7.76 \pm 0.4 \%$, and physically active without historical chronic complications volunteered to this study. In the MI protocol, subjects remained at a constant rate for $30 \mathrm{~min}$ to maximum $60 \%$ of the estimated heart rate. In the HIIT protocol, individuals ran for $1 \mathrm{~min}$ at high intensity (higher than $90 \% \mathrm{HR}$ ) and walked $1 \mathrm{~min} 5 \mathrm{~km} / \mathrm{h}$ for $20 \mathrm{~min}$. Samples were collected in two different days, with an interval of $48 \mathrm{~h}$ between them. The first day was composed of physical assessment, dietary investigation of the last $24 \mathrm{~h}$ and realization of the first protocol exercise. The second day also consisted of food recall for the last $24 \mathrm{~h}$ and realization of the second protocol exercise. The protocols were assigned randomly. During exercise protocols, perceived exertion (PSE), heart rate (HR), blood pressure (BP) and

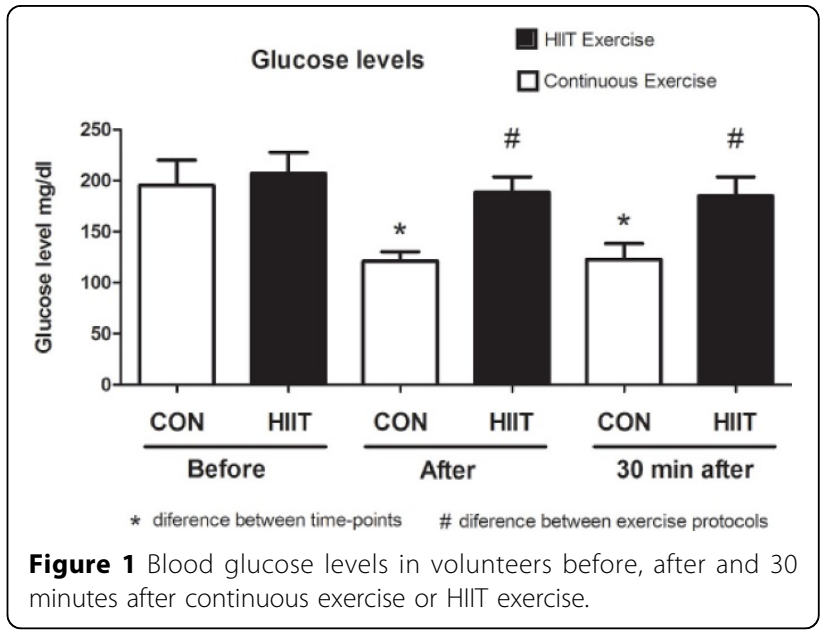

capillary glucose levels were collected immediately before and after and $30 \mathrm{~min}$ after the test.

\section{Results}

Both performed protocols resulted in blood glucose level decrease in volunteers. However, HIIT promoted a significantly smaller decrease compared to MI (Figure 1) immediately $(\mathrm{p}=0.01)$ and $30 \mathrm{~min}(\mathrm{p}=0.02)$ after exercise.

\section{Conclusion}

Both exercise protocols induced glucose reduction in peripheral blood. However, the decline in blood glucose was significantly lower in the HIIT protocol when compared to the MI in DM1.

\footnotetext{
* Correspondence: william.valadares@yahoo.com.br Universidade Federal de Minas Gerais/ICB, Brazil
} 
doi:10.1186/1758-5996-7-S1-A228

Cite this article as: Oliveira et al: Comparison of capilary glycemic responses after moderated continuous racing and high-intensity interval training in diabetes type 1 patients. Diabetology \& Metabolic Syndrome 2015 7(Suppl 1):A228.

Submit your next manuscript to BioMed Central and take full advantage of:

- Convenient online submission

- Thorough peer review

- No space constraints or color figure charges

- Immediate publication on acceptance

- Inclusion in PubMed, CAS, Scopus and Google Scholar

- Research which is freely available for redistribution

Submit your manuscript at www.biomedcentral.com/submit 